\title{
Reflections on the Spiritual Dynamics of the Bahá'í Faith
}

\author{
Alessandro Bausani
}

\begin{abstract}
True spiritual force has the power to change matter. The spiritual force released by Bahá'u'lláh has the power to change the entire world. Humans, unaided, cannot understand the fundamental problems of mankind; a prophet like Bahá'u'lláh gives us the power both to understand human problems and to correct them. Values do not derive from the individual but from the central Force of the universe: God. Only the religious mind can place moral issues like sin and death in the context of the realities of the universe. The acquisition of virtues such as a love of order, moderation, obedience, and humility are among the requisites for preparing the human heart for the new society Bahá'u'lláh's teachings will bring. However, religion should be practical and other-oriented, not mystical and introspective. The spiritual force released by the good actions of believers has a more pervasive influence than the same action of a nonbeliever. The gathering together of Bahá'ís in prayer will augment these spiritual forces and dispel ignorant ideas of religion.
\end{abstract}

\section{Résumé}

Une véritable force spirituelle a le pouvoir de transformer la matiére. La force spirituelle libérée par Bahá'u'lláh détient ce pouvoir de transformer Ie monde entier. Sans assistance divine, les êtres humains ne peuvent appréhender les problèmes fondamentaux de l'humanité; un prophete tel que Bahá'u'lláh nous donne à la fois la capacité de comprendre les problèmes humains et la possibilité de les corriger. Ce n'est pas de l'individu que découlent les valeurs mais de la force qui est au centre de l'univers: Dieu. Seul un esprit religieux est en mesure de replacer des questions morales comme Ie péché et la mort dans Ie contexte des réalités qui composent l'univers. L'acquisition de vertus telles que l'amour de l'ordre, la modération, l'obéissance et l'humilité font partie des qualités indispensables pour préparer Ie coeur humain à cette nouvelle société que les enseignements de Bahá'u'lláh sont en train de créer. La religion devrait toutefois posséder un aspect pratique et altruiste au lieu d'être mystique et introspective. La force spirituelle libérée par les bonnes actions des croyants possède une influence à la fois plus pénétrante et plus englobante qu'une action identique entreprise par un non-croyant. Le rassemblement des bahá'ís dans la prière accroîtra ces forces spirituelles et dissipera les préjugés en matière de religion.

\section{Résumen}

La fuerza espiritual verdadera tiene el poder de cambiar la materia. La fuerza espiritual desatada por Bahá'u'lláh tiene el poder de cambiar al mundo entero. Los humanos, sin ayuda, no pueden entender los problemas fundamentales de la humanidad; un profeta como Bahá'u'lláh nos da tanto el poder de entender los problemas humanos y de corregirlos. Los valores no provienen del individuo sino de la fuerza central del universo: Dios. Sólo la mente religiosa puede poner cuestiones morales de pecado y muerte en el contexto de la realidad del universo. La acquisición de virtudes como el amor al orden, moderación, obedencia, y humildad son algunos de los requisitos para preparar al corazón humano para la nueva sociedad que las enseñanzas de Bahá'u'lláh nos brindará. Sin embargo, la religión debe de ser práctica y orientada hacia otros, no mística e introspectiva. La fuerza espiritual desatada por las buenas acciones de los creyentes tiene una influencia más pervasiva que las mismas acciones por los no-creyentes. Al reunirse juntos los Bahá'ís en oración aumentarán estas fuerzas espirituales, y dispersarán las ideas ignorantes sobre la religión.

For Bahá'ís, the term "spiritual" has a clear and positive value. Positive value means that spirit has power, that spirit does not fly away from matter, but instead has the power to change matter. Bahá'u'lláh likened man to a powerful bird that cannot fly with a single wing; man's wings are both of spirit and matter. Through spirit, a flower can spring out of earth; the flower is unthinkable without the spiritual force organizing the material elements in the earth to create that flower. Through that same spirit, and yet in another plane, Moses created the flower of the "people of God" from the barren soil of the heart of the Israelites. Muhammad made of the sunburnt sands of the Arabian desert a spiritual paradise and a source of life to generations.

Through that same spiritual force, Bahá'u'lláh, an unknown man from an almost unknown comer of the world, a prisoner without any material assistance of arms and bayonets (or atomic bombs), accomplished this miracle of uniting people from the farthest regions of the earth, giving Bahá'ís all over the world a practical, organized, and well-ordered force to change the world.

This is what I mean by spiritual dynamics. A true spiritual force, possessing real strength to change the 
world can be found only in a faith, in a religion. I think it necessary, especially before persons who could mistake the Bahá'í Faith for a purely humanistic organism, to emphasize the basic religious character of the Bahá'í Faith. I see the Bahá'í Faith as the religion rather than $a$ religion, acknowledging as it does all the prophets and fundamental truths of all established religions. Yet, with its veneration for the Eternal Christ shining in Bahá'u'lláh, with its simple and democratic yet well-organized, extremely dis ciplined Administrative Order (believed by Baháís to be based on nothing less than the Word of God and thus different from all manmade churches and organizations), it forms a unique body of persons believing with all their hearts in God, considering all that is not of God as ephemeral, and believing that God's aim is now the unification of the human race and striving hard for this supreme goal.

Those of you who are not believers of any religion will certainly ask me: do you really think that a prophet and a religion and God are needed to unify the world? It would be very easy to answer by mentioning some of the numberless facts proving the futility of human efforts, even when aided by powerful modern means, to construct at least a partial unity in our world and comparing these with the wonderful achievements of Moses, Jesus, and Muhammad. But I will rather try to explain, in a more theoretical way, why I believe that religion is the only power possessing a "spiritual force," the special force mentioned earlier.

Religion means absolute unity in diversity. When I say absolute, I mean a unity embracing all, not a partial unity. Modern science has demonstrated that the entire universe is a complex of nothingness held together by energies and forces of a character extremely difficult to explain in simple words. "Nothing nesses" like death, evil, and sin have no place in a world-synthesis of a nonreligious character, at least they are not understandable by nonreligious minds.

The sacred force of the unifying power of religion lies in the fact that the religious mind doesn't neglect problems like those of death, evil, and sin. On the contrary, it gives them their proper place in the immense order of the cosmos and illuminates them with a suitable light. This power of absorbing and assimilating into a great system things like "death," "evil," and "sin" can't be given naturally; it is not a power of nature, itself a part of the whole. The unifying power must lie in a region beyond nature and non-nature, even beyond "spirit" in the obvious psychic sense of the word (itself always a part).

Imagine a beautiful painting and then a colored dot in this painting trying to understand-on its bidimensional plane - the entire painting. The colored dot cannot in any way, even travelling throughout the entire picture of which it is a part with its unique place and color, understand the unity of the picture; even less so can it unify and arrange colors and lines of the painting if some disorder takes place. Only by placing itself outside the painting, only by looking at the painting with the eyes of the painter, comprehending the picture and its surroundings, only in this way could it understand the real meaning of the painting and at the same time obtain the force necessary to correct, order, and better unify it. Man alone cannot understand humanity, and therefore Bahá'ís think that a Superman can teach us this: a Superman not in Nietzsche's pagan sense (more infrahuman than superhuman) but rather, what we call a prophet. A prophet is both a teacher (to understand what the painting is and why it has been made) and a giver of power (to correct it, because we think, as the Qur'án says, that God is never tired of creating and renewing things). The only difference between Baháís and other religious people is that according to Bahá'í teachings, God's richness is so great that a single prophet is not sufficient to reveal this richness, and so Baháís believe in an uninterrupted series of revealers of divine bounty, increasingly adapted to the intellectual and moral progress of mankind, so as to avoid crystallization and ritualistic manmade traditionalisms.

This dynamic power of changing the world is bestowed by God upon humanity-whose dignity and supreme position in the universe is strongly emphasized by the Bahai Faith-only after a preliminary cleansing of the heart. The cleansing instruments are order, moderation, obedience, and humility.

\section{Order}

By order I mean, of course, not a geometrical, purely mental and abstract disposition of things, but rather something quite different. Modem people, and specially young revolutionary generations including myself some years ago, are terrified hearing words like order and moderation. But the order of the Baháís does not mean a return to the Middle Ages. Rather, it means creating, from the universal point of view of the Painter, a new and more beautiful arrangement in the picture.

\section{Moderation}

To Bahá'ís, moderation means discerning the truth in all things as seen with the eye of God. More than eighty years ago, Baháu'lláh told the world: 'Soon will the present-day order be rolled up, and a new one spread out in its stead" ( Gleanings 7). To develop a spirit—so to say-of artistic order in ourselves is one of the chief preparatory tasks of religious persons. It is what in medieval theology was called "asceticism," and what the Bahá'ís can now exercise in a new and interesting way, repudiating nothing of the beautiful things of this world of God, in their well-organized and collectively-working communities held together by ordinances laid down by the Prophet Baháu'lláh, perfected by his son, 'Abdu'l-Bahá, and evolving in time under the direction 
of the Universal House of Justice. A characteristic feature of this Order, completely lacking in the modem world, is obedience, obedience not to man but to God.

\section{Obedience}

The modem world has often strangely preferred obedience even to the most unworthy individuals than to God. I know many persons in my country [Italy], who when discussing the existence of God, accused me of being a slaveminded man because of my belief in a supreme Lord and Master, and then themselves completely relinquished their rational powers before a dictator. If obedience to a partial power, to a part often in conflict with the whole, means abasement and self-mortification, obedience to a universal or, better said, superuniversal Power, means being ourselves a part of this creative whole: something then opens in us, a portal from which creative forces flow into our being.

\section{Humility}

Humility, the other forgotten virtue, is connected with all this. It means that "devotional" attitude of mind, so rare now, at least in our Western world, and that which gives humanity the possibility of recognizing everywhere the voice of God. A well-known Persian mystic poem says, "We must have a king-recognizing eye so as to recognize the king in every dress, even in the dress of a beggar." This attitude to believe, when rooted in a pure heart, is really infallible. This attitude to kneel before something majestic and divine, for example was lacking in the Pharisees at the time of Jesus, a king who appeared in the dress of a beggar. So it was for Baháu'lláh, a persecuted pris oner dispossessed of even a trace of human and earthly power. I admit that this virtue is very difficult for modem people, but I don't admit that it is not a virtue. I am sure that if Jesus, whom Christians theoretically so venerate, would come now in the world exactly in his same garb, saying the same things, He would certainly finish in a prison or an insane asylum. Why? Because of humanity's lack of humility. One of the most important spiritual experiences of being a Bahai is this possibility of exercizing now -in our world with its atomic bombs, airplanes, electricity - the same virtue that gave to the ancient Christians the possibility of recognizing the Christ in Jesus. Bahá'ís believe that the Christ for our era is Baháu'lláh.

These virtues are the preparation, the cleansing instruments for the heart. The creative forces generated after cleansing are a gift of God, and it is, of course, very difficult to explain them in words. It is what every religion calls faith. But after what I said before, don't think that the Bahá'í Faith is a medieval faith denying everything terrestrial and only looking at the heavens. On the contrary, the Bahá' Faith is not mystic in the otherworldly sense of the word. In a letter by Baháu'lláh to a friend of his who was a mystic, there is a very interesting passage advising the friend to follow another way, with these words:

Open thy spiritual wings and soar through all the spiritual kingdoms with the swiftness of a lightning. Fling wide open the vision of thy eyes and regard the grace of the invisible world. If thou throwest mud into the water it sinks, but if thou depositest a rose into it, it remains like a crown floating upon it: i.e., záhir and baqá (exteriority and permanence) are better than bátin and faná (interiority and annihilation). In other words weight is the cause of sinking, therefore thou must free thyself from the weight of possessions, and, like a rose, in this very bodily frame float through eternity upon the surface of earthly dominions.

This passage has a meaning much deeper than what appears at first sight. Though emphasizing detachment from earthly possessions and the importance of the invisible world, it contains a very fine criticism of that system or those systems of religious mysticism (so frequent in oriental countries and often a cause of decay for those peoples), which assume that sinking into oneself, shutting one's eyes to every exterior reality, is the supreme goal of man. In the words of Baháu'lláh, we have an interesting religious revindication of exoter ism and activity against the exaggerated importance given by almost all religions to meditation and annihilation. The rose can't do any good if thrown and sunk into the water. Like the metaphorical rose, we must float upon earthly things through eternity, that is, dominating earthly things and putting them into the great invisible frame of a divinely appointed Order. Doing something with them, not sinking into them.

Another very interesting point in Baháu'lláh's criticism of certain mystic lore is that too often pseudoreligious persons, imagining they are deeply sinking into unheard of spiritual abysses, do nothing more than mix up their own subconscious and unconscious zones. Even great mystics, said Baháu'lláh in another letter, took their poetical imaginings about God for reality. Only God, and this is a central point in the Bahá' teachings, only God speaking through his Manifestations can inspire humanity with creative thoughts, which result in creative action.

Baháu'lláh says: "He [the non-believer] is the people of error, though he shows forth all good actions" (Kitáb-i-Aqdas). And "Abdu'l-Bahá explains: "This blessed verse means that the foundation of success and salvation is the knowledge of God, and that the results of the knowledge of God are the good actions which are the fruits of faith" ( Some Answered Questions 238).

This may sound rather horrifying to modern ears. Modern philosophies of religion are more and more reducing 
religion, in the best case, to purely moral phenomena. Religion and morals are identified by philosophers. This sentence of Bahá'u'lláh speaks against this too unilateral conception. According to the Bahá'í Faith, a good action is, of course, always a good action, but a good action performed by a believer has a special creative force.

We ought always to bear in mind that we are not ourselves the creators of values. Values flow through us from the central creative force of the universe. If we direct ourselves towards that center, if we choose the exact channel through which that force is flowing, it is clear that every action (value) we personally create becomes infinitely multiplied by the creative power. In other words, if a nonbeliever does a good action, this produces a force (and I do not deny that this is a positive one too) whose radius of action is limited by the real, but partial, energy of that particular man or particular manmade doctrine. But if a believer does a good action, new flowers blossom on all the planets; new wonderful portals open in the whole of the universe. Sometimes the special power of a good deed performed by a believer can't be seen by mortal eyes; it is like every normal good deed in this world. But sometimes even unbelieving eyes must acknowledge this unheard of force. Take, for instance, the immense power acquired through the Word of God by those ignorant Muslim bedouins who established the most powerful civilization of their times after the collapse of both the Persian and Byzantine Empires, or those Christian martyrs who created our occidental civilization, or those thousands of Bahá'ís who died for their faith in Persia, laying the first foundations of the World Order.

Modern society can no longer be satisfied with a doctrine concentrating every source of value in the individual. Individualism, represented in the religious field especially by the great Protestant Reformation and in politics by Liberalism, has had its time. The best proof of this is the increasing power of attraction on the masses exercized by great collectivistic parties and religious organizations. The different values, religious and private, of good deeds is strictly connected with the social problem: the force of religions, especially at their native and original and fresh stages, consists in the fact that they boldly assert that only God can do good, in the real cosmic sense of the word, whereas the private and personal actions of men, even heroic, have their private and personal value. The doctrine that made "Jesus is my personal Savior" the center of religious emotion is not enough for a modern soul. The spiritual and mystic center, from which all the social teachings of the Bahá'i Faith develop, is this sentence of Bahá'u'lláh, "The mere act of your gathering together is enough to scatter the forces of these vain and worthless people" (Tablets 85).

Gathering together in spirit of prayer, that is, shaking hands in fraternal love, my white hands with the black ones of a Negro, my Italian hands with the hands of an Englishman, has a transforming power far above that of sacraments and rituals. Working together is an act of worship in the Bahá' Faith. But, this is the central point, in the spirit of prayer, a spirit that led Baháu 'lláh to pray:

O my God! O my God! Unite the hearts of Thy servants, and reveal to them Thy great purpose [the unity of mankind]. May they follow Thy commandments and abide in Thy law. Help them, O God, in their endeavor, and grant them strength to serve Thee.... (Prayers 204)

\section{Works Cited}

'Abdu'l-Bahá. Some Answered Questions. Trans. Laura Clifford Barney. Wilmette: Baháí Publishing Trust, 1981.

Bahá'í Prayers: A Selection of Prayers. Wilmette: Bahá’í Publishing Trust, 1985.

Bahá'u’lláh. Gleanings from the Writings of Bahá'u'lláh. Trans. Shoghi Effendi. Wilmette: Baháí Publishing Trust, 1952.

- A Synopsis and Codification of the Kitáb-i-Aqdas. Trans. Shoghi Effendi. Haifa: Baháí World Centre, 1973.

— Tablets of Bahá'u’lláh. Camp. Research Department. Trans. Habib Taherzadeh. Haifa: Bahá'í World Centre, 1978. 